\title{
RESULTS OF GEOCHEMICAL MONITORING OF THE ACTIVITY OF EBEKO VOLCANO (KURILE ISLANDS) USED FOR ERUPTION PREDICTION.
}

\author{
I. A. MENYAILOV, L. P. NIKITINA and V. N. SHAPAR \\ Institute of Volcanology, Petropavlovsk-Kamchatsky, 683006 USSR. \\ (Received December 20, 1984)
}

\section{ABSTRACT}

Menyailov, I. A., Nikitina, L. P. and Shapar, V. N., 1985. Results of geochemical monitoring of the activity of Ebeko volcano (Kurile Islands) used for eruption prediction. Journal of Geodynamics, 3: $259-274$.

The monitoring of the state of active volcanoes, carried out using different parameters, including geochemical, is very important for studies of deep processes and geodynamics. All changes which occur within the crater before eruptions reflect the magma activation and depend on the deep structure of volcano. This paper gives the results of prolonged monitoring of Ebeko volcano, located in the contact zone between the oceanic and continental plates (the Kurile Island Arc). The geochemical method has been used as the basis for eruption prediction because the increase in the activity of the Ebeko in the period from 1963 to 1967 that ended in a phreatic eruption was not preceded by seismic preparation. Investigations carried out at Ebeko volcano give evidence that change of all the chosen geochemical parameters is a prognostic indicator of a forthcoming eruption. This change depends on the type of eruption, and the deep structure and hydrodynamic regime of the volcano.

\section{INTRODUCTION}

The first volcanological observatory in Kamchatka was established in 1935 and work immediately began on the systematic study of the active volcanoes, including monitoring of Klyuchevskoy, Bezymianny and Shiveluch, the most active volcanoes of Central Kamchatka (Basharina, $1956 ; 1963 ; 1966)$. Monitoring included annual surveillance of the state of volcanoes, temperature measurements, and sampling and analysis of fumarolic gases, their condensates and mineral incrustations. During the past 50 years, Soviet volcanologists have developed and improved methods of sampling and analysis of volcanic gases. The present paper discusses the results of many years of monitoring the state of Ebeko volcano carried out by the authors to find precursors to volcanic eruptions in variations of tem- 
perature and fumarolic gas composition in order to forecast the onset of forthcoming eruptions. Results of monitoring of the state of active volcanoes are very important for understanding deep processes and geodynamics since they reflect the prolonged temporal variations in the energetic, heat and chemical regimes of volcanoes.

\section{Sampling and Analysis of Volcanic Gases}

A method of gas sampling is based on the separation of gas mixtures in situ. A gas-collection system includes a quartz tube, vessels for the absorption of acidic gases and a measuring pipette (Fig. 1). In the first absorption vessel a condensate is formed and $\mathrm{HF}, \mathrm{HCl}$ and $\mathrm{SO}_{2}$ are absorbed. In the next absorption vessel, filled with cadmium-acetate solution,

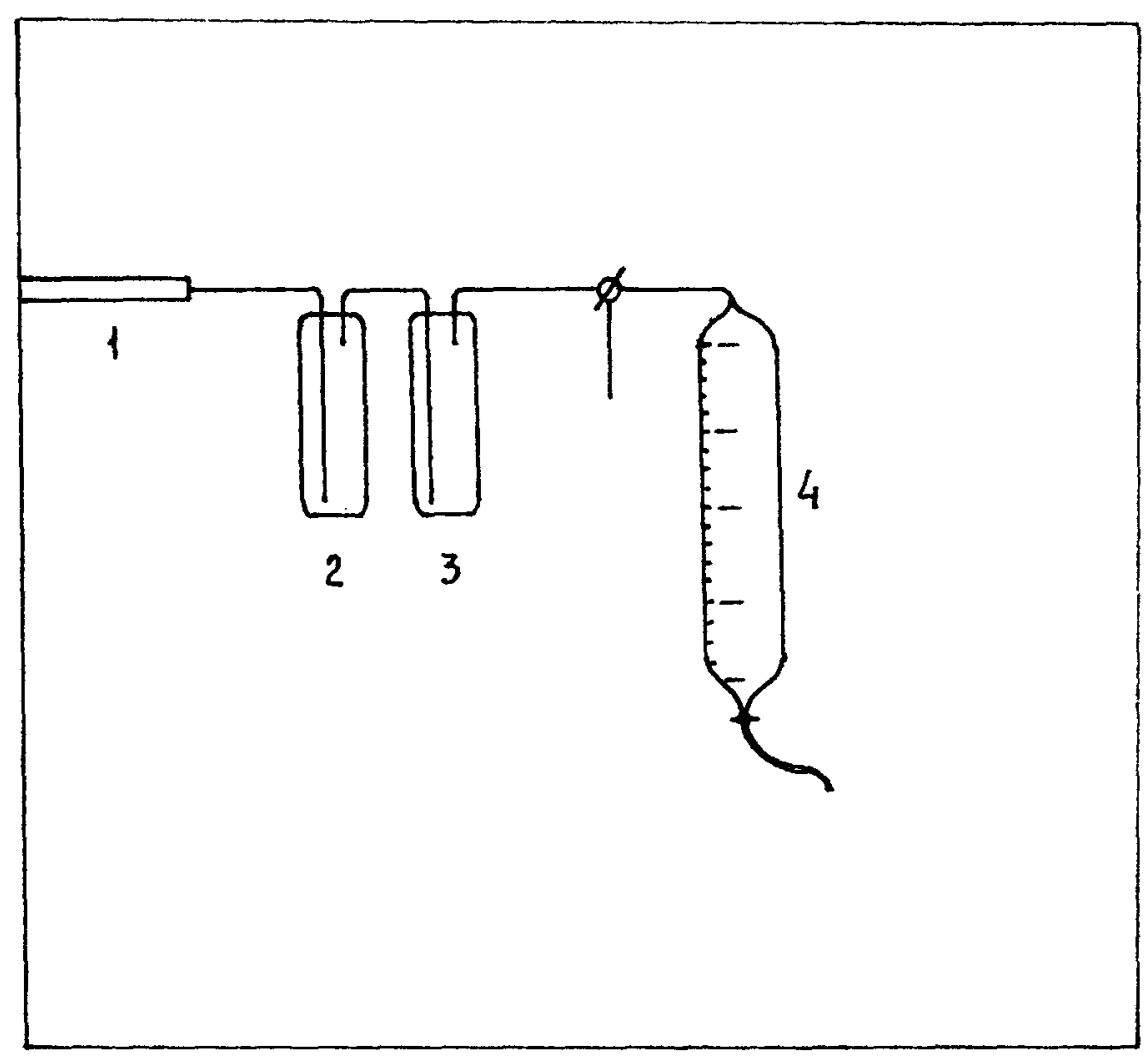

Fig. 1. The system of gas sampling used at Ebeko volcano. 1. quartz pipe, 2. absorption vessel with tridistilled water for $\mathrm{H}_{2} \mathrm{O}, \mathrm{HF}, \mathrm{HCl}, \mathrm{SO}_{2}$ and metal absorption, 3. absorption vessel with cadmiumacetate solution for $\mathrm{H}_{2} \mathrm{~S}$ absorption, 4. measuring pipette for unabsorbed gases $\left(\mathrm{CO}_{2}, \mathrm{CO}, \mathrm{H}_{2}, \mathrm{CH}_{4}, \mathrm{O}_{2}\right.$, $\mathrm{N}_{2}, \mathrm{Ar}$ ). 
$\mathrm{H}_{2} \mathrm{~S}$ is absorbed. Separately, a sample is placed into the suspended vacuum absorption vessel, filled with cadmium-acetate solution, to check the $\mathrm{H}_{2} \mathrm{O}$ and $\mathrm{CO}_{2}$ contents. The measuring pipette is used to determine the volume and to sample the unabsorbed gases $\left(\mathrm{CO}_{2}, \mathrm{CO}, \mathrm{H}_{2}, \mathrm{CH}_{4}, \mathrm{O}_{2}, \mathrm{~N}_{2}, \mathrm{Ar}\right.$, and $\mathrm{He}$ ). Small amounts of $\mathrm{CO}$ and $\mathrm{CH}_{4}$ are determined using a separate sample of enriched gases from which $\mathrm{CO}_{2}$ is preliminarily absorbed by the causticsoda solution.

Analyses of volcanic gases are made in a field or a stationary chemical laboratory. Acid gases are determined by chemical analysis of liquid solutions. The unabsorbed gases are determined by gas chromatography. Simultaneously, condensate sampling is carried out to determine the isotopic composition of volcanic water. The isotopic composition of $\mathrm{CO}_{2}$ and noble gases is determined by gas analysis from a measuring pipette. Metals are analysed in absorbent liquids or by the direct method using filters or, after preliminary concentration, by the methods of "wet" chemistry, atomic absorption and neutron-activation (Menyailov et al., 1980).

The method of sampling and analysis of volcanic gases developed and improved upon at the Institute of Volcanology was used at numerous volcanoes of Kamchatka, the Kurile Islands, Italy and Nicaragua. The method is simple, reliable in work at active volcanoes, and the main feature is that it allows determination of numerous geochemical parameters, including the chemical and isotopic compositions.

\section{Geology of Ebeko Volcano}

In 1964 the team from the Institute of Volcanology charged with the sampling and analysis of volcanic gases began the monitoring of geochemical parameters at Ebeko volcano located on Paramushir Island, North Kuriles. Prior to 1964, our colleagues from the Sakhalin Complex Institute carried out analogous studies (Surnina and Voronova, 1964; Voronova and Sidorov, 1966; Experience in Cooperative Study ..., 1966). These works are of great practical importance because the volcano threatens a town which is located at a distance of $12 \mathrm{~km}$ from the crater.

The Quaternary Ebeko volcano formed in the Vernadsky Ridge prior to the epoch of the first glaciation (Experience in Cooperative Study..., 1966). The preglacial volcanic edifice was composed of bipyroxene andesites and andesite-dacites. The contemporary cone, with a chain of craters at the summit, formed in the post-glacial epoch. The products of recent activity are lava flows of andesite composition. Gigantic bombs of the "bread-crust" type found on its slopes are composed of andesites and are associated with recent Ebeko activity (Experience in Cooperative Study..., 1966). The 
eruptive activity of Ebeko volcano was accompanied by strong hydrothermal processes and by solfatara activity. As a result, andesites composing the volcanic edifice are strongly altered, forming opalites, quartzites, alunites, etc. The altered rocks contain significant accumulations of native sulfur.

The absolute altitude of the volcano is $1037 \mathrm{~m}$. The relative altitude of the active cone is about $250 \mathrm{~m}$. The top of the cone is crowned by three craters (Fig. 2). The middle crater contains a cold lake; another lake, filled with hot water, lies in the northern (lower) crater. Numerous solfataras occur on the floors of the craters and on the outer slopes of the cone. They form a few solfatara fields. Continuous temperature measurements and sampling of the "Gremuchaya" and "Revushchaya" solfataric gases were carried out (Tables 1,2). In addition the state of solfataras in other fields was also investigated.

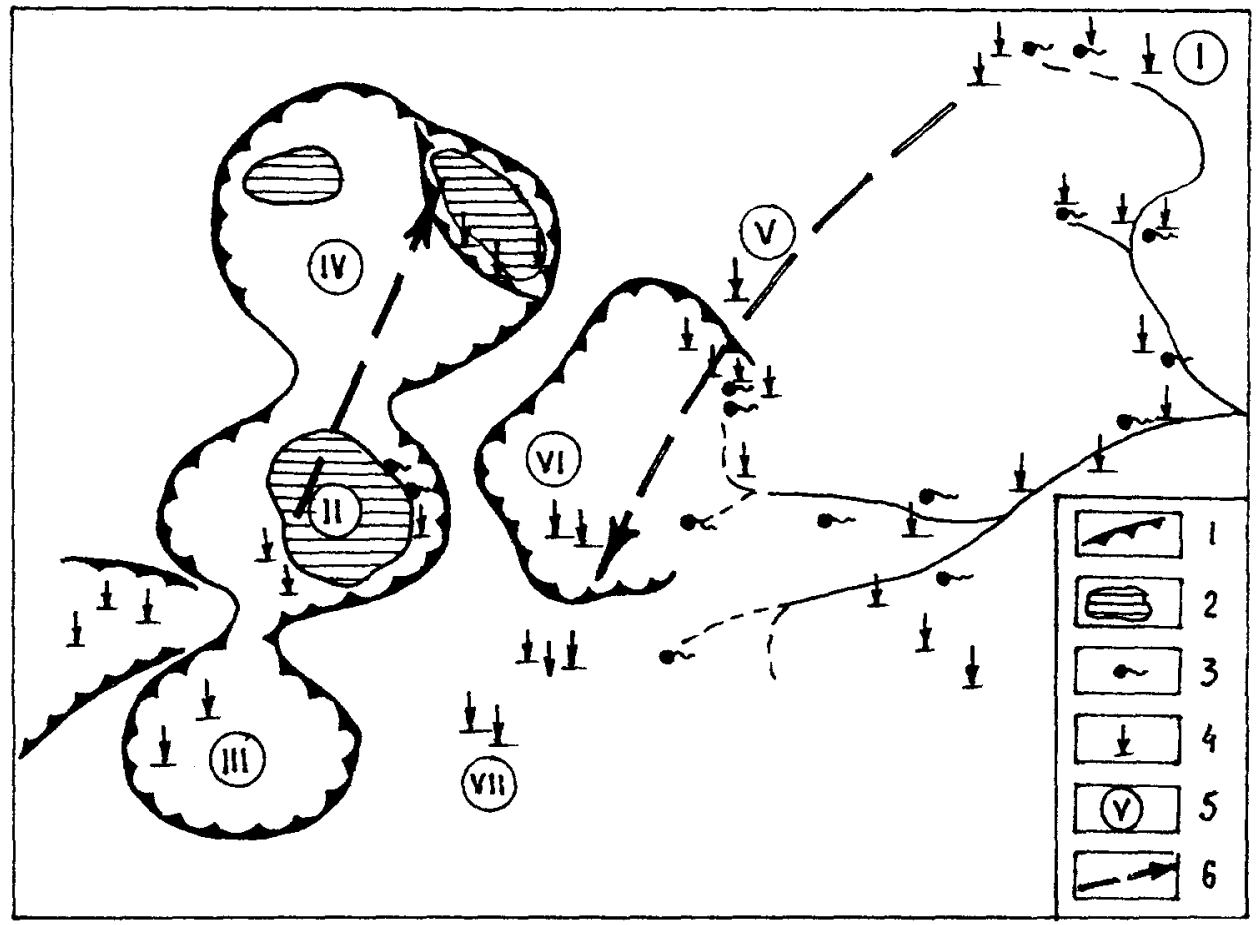

Fig. 2. Schematic map of the summit portion of Ebeko volcano. I. Northeastern field where the "Revushchie" solfataras occur; II. Middle crater lake; III. Upper crater; IV. Northern crater and the 1967 phreatic eruption funnel; V. "Gremuchaya" solfatara; VI. Eastern circus fields where the temperature increase was observed in 1983; VII. Western field.

1. scarps; 2. warm lakes; 3 . hot springs; 4. solfataras; 5 . solfatara fields. 


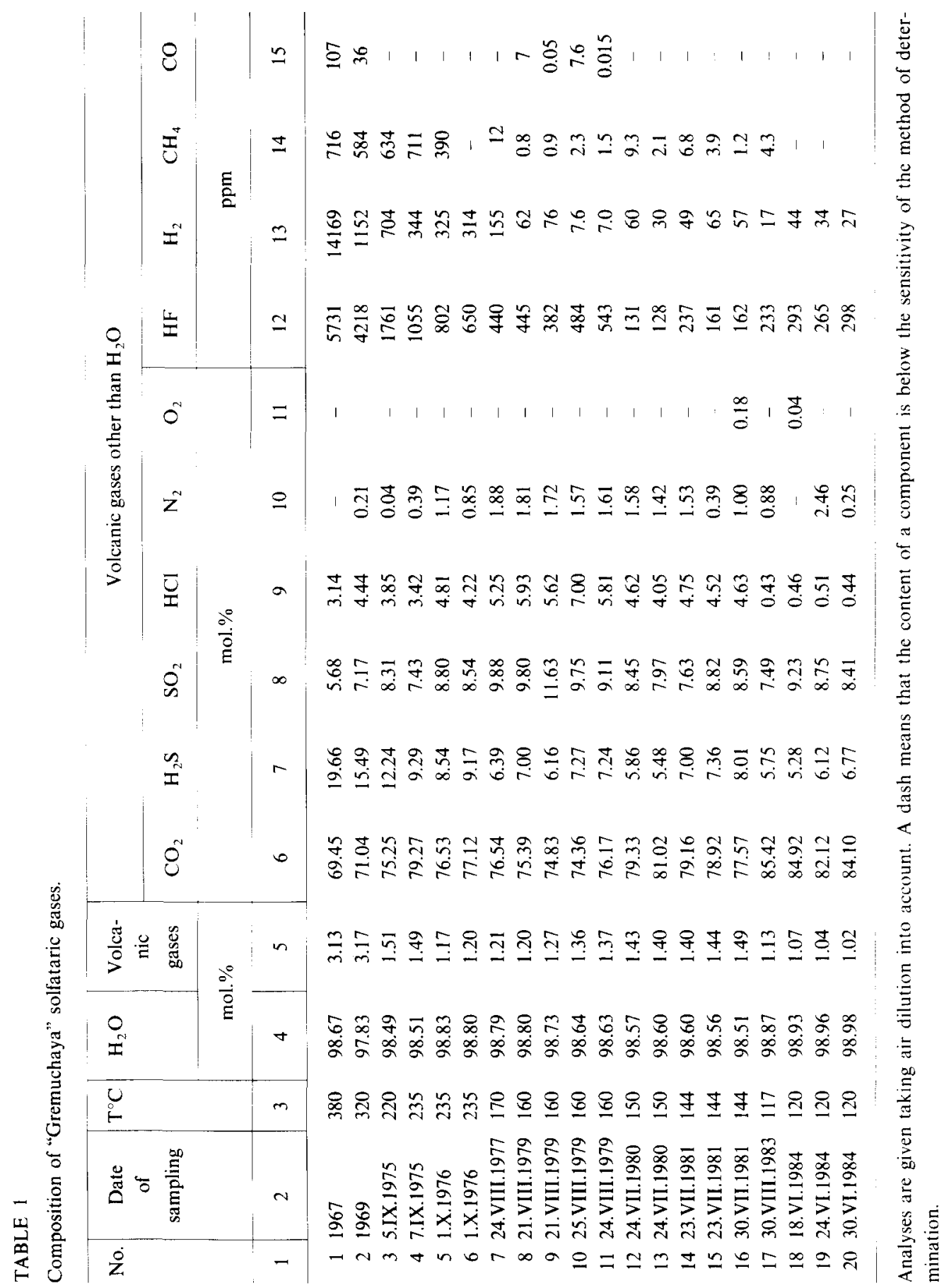




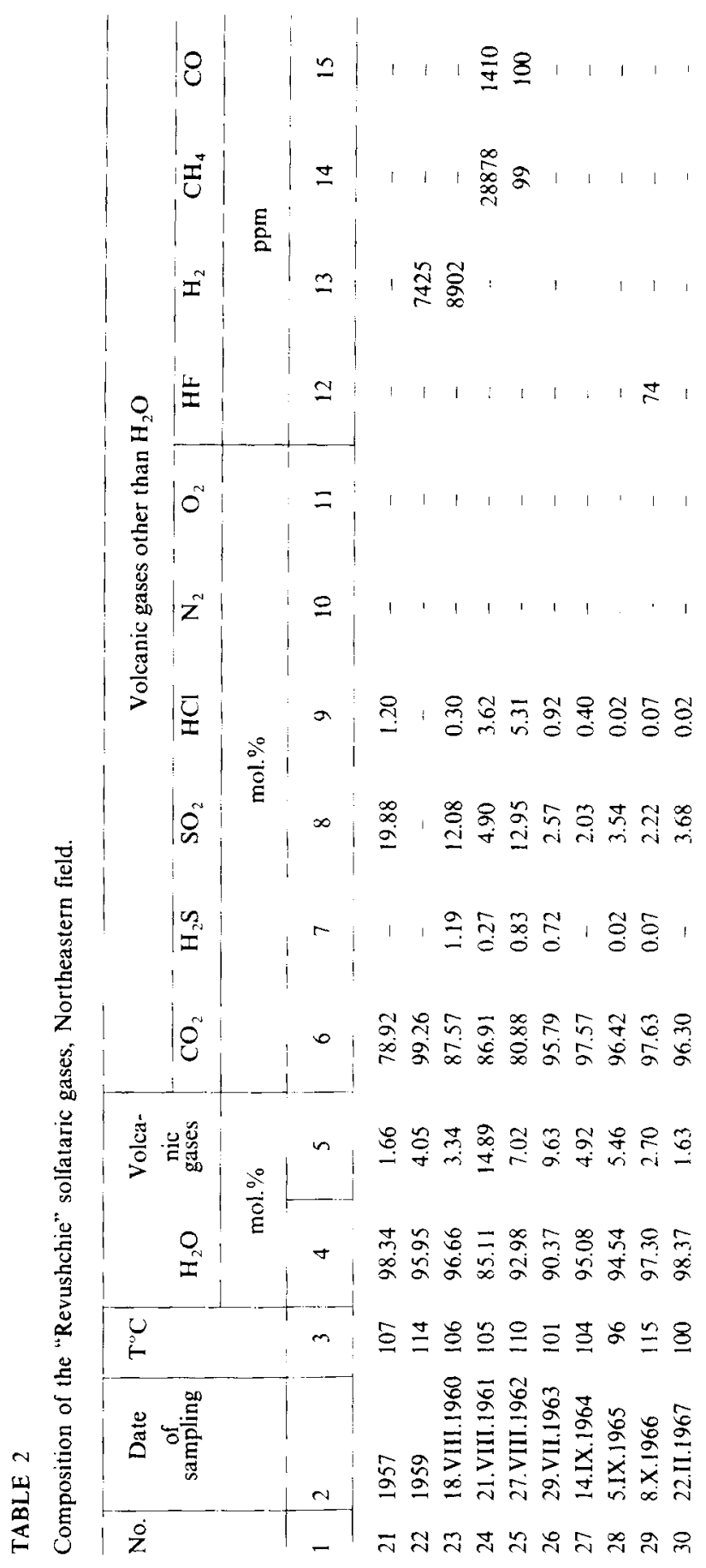




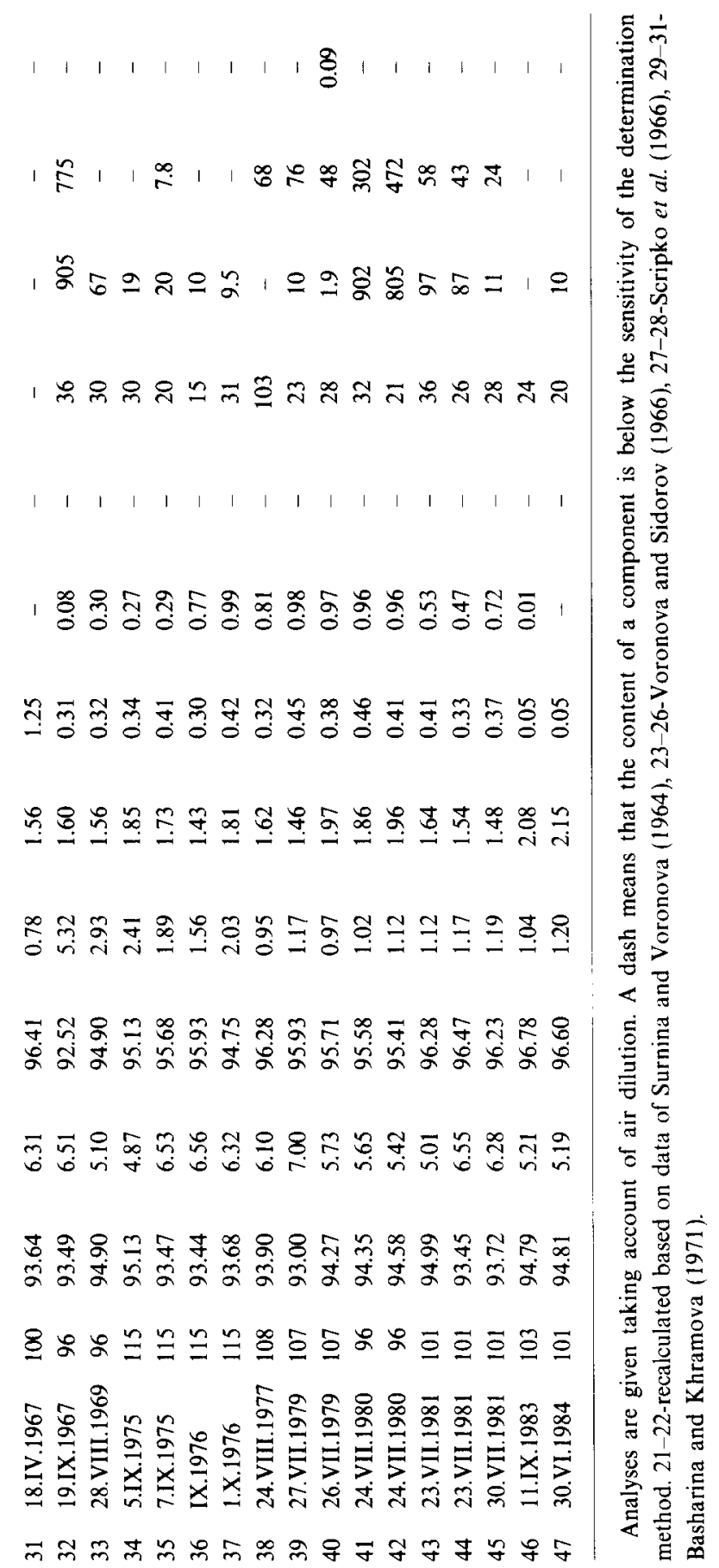




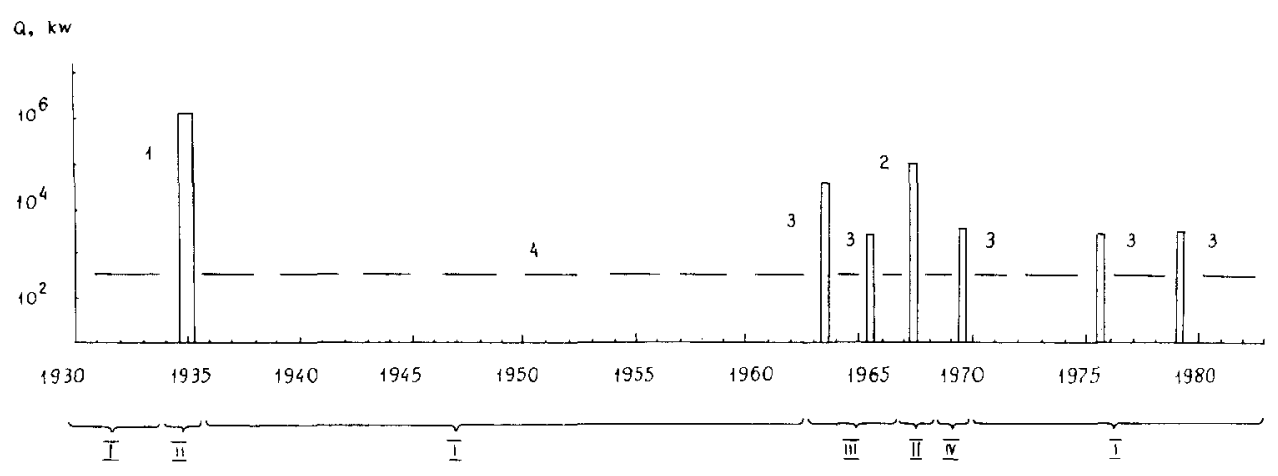

Fig. 3. Intensity of explosive and fumarolic activity in the different periods of Ebeko's eruptive cycle. $\mathrm{Q}(\mathrm{KW})$-heat power of gas pyroclastic and fumarolic plumes calculated according to Fedotov's formula (Fedotov, 1982). The height of plumes is given based on data of Gorshkov (1967), Kirsanov et al. (1964) and Menyailov et al. (1969).

1. the 1934-1935 paroxysmal Vulcanian eruption; 2. the 1967 interparoxysmal phreatic eruption;

3. intensification of gas emission in 1963 through 1975; 4. the usual fumarolic activity.

I. intereruptive period; II. eruptive period; III. pre-eruptive period; IV. posteruptive period.

\section{Eruptive History of Ebeko Volcano}

During the XXth century, several eruptions of the volcano were recorded. Four types of activity could be distinguished in the eruptive cycle* of the volcano, namely, paroxymal eruption of Vulcanian type, possibly with lava effusion; interparoxymal eruption of phreatic type; intensification of gas emission and constant solfatara activity (Fig. 3). The paroxymal eruption which was taken to be the beginning of the most recent eruptive cycle of the volcano occurred in 1934-1935 from the middle crater (Gorshkov, 1967). As a result of this eruption, about $1 \times 10^{6} \mathrm{t}$ of andesitic ash and bombs were ejected. Intensification of gas emission from the funnel-like vent on the eastern slope of the volcano, accompanied by self-ignition of native sulfur and by the formation of melted sulfur flows, was observed in 1963 (Kirsanov et al., 1963). In 1965 another intensification of gas emission from the middle crater was observed (Scripko et al., 1966). Intensifications of gas emission preceded an interparoxysmal eruption of phreatic type which occurred from the northern crater in February 1967 (Menyailov et al., 1969). As a result of this eruption, a funnel was formed on the floor of the crater and about $1.2 \times 10^{5} \mathrm{t}$ of strongly altered fragments and ashes of andesite composition were ejected. After the 1967 phreatic eruption, intensification of gas emission was again observed in 1969.

* The bounds of eruptive cycles are fixed by large paroxysmal eruptions (after Piyp, 1956). 
Before the intensification of volcanic activity in 1963-1967, the most violent "Revushchie" solfataras occurred in the region of the northeastern field. Approximately fifty percent of the heat $\left(\sim 2.5 \times 10^{7} \mathrm{kkal} / \mathrm{h}\right)$ was released by solfataras from all gas vents at the volcano (Nekhoroshev, 1960). After the 1967 eruption, up to 1983 , approximately $50 \%$ of the heat was released by the "Gremuchaya" solfataras and the total amount of heat released by all gas vents, according to our measurements in 1979, did not change significantly. In 1983 the center of the heat emission migrated 200-250 m west of "Gremuchaya" solfatara. Here, in the region of the Eastern circus solfataras, an increase in temperature and gas discharge was observed. In 1983, as previously, the total amount of heat released by fumaroles did not change. Figure 2 shows the migration of the centers of the activity of Ebeko.

\section{Variations in Geochemical Parameters Depending on the State of Volcanic Activity}

Now we shall consider the variations in geochemical parameters for gases of the routine solfataras, depending on the state of volcanic activity, during the period from 1057 to the present time.

The "Gremuchaya" solfatara formed after the 1963 intensification of gas emission. A short-term increase in temperature of solfataric gases near their vents from $120^{\circ} \mathrm{C}$ to $350^{\circ} \mathrm{C}$ was noted in September 1963 (Fig. 4). From then until December 1966 , their temperature was approximately $140^{\circ} \mathrm{C}$. During the 1967 phreatic eruption, the temperature increased to $380^{\circ} \mathrm{C}$. In 1969 the temperature was $320^{\circ} \mathrm{C}$, then it began to decrease gradually and in the period from 1980 to 1983 it was $140-150^{\circ} \mathrm{C}$. In 1983 the temperature decreased abruptly to $117-120^{\circ} \mathrm{C}$.

Against the background of the gradual decrease of the temperature of the "Gremuchaya" solfataric gases, the $\mathrm{H}_{2} \mathrm{O}$ content increased and the $\mathrm{H}_{2}$ content decreased, while the $\mathrm{H}_{2} \mathrm{O} / \mathrm{CO}_{2}$ and $\mathrm{CO}_{2} / \mathrm{H}_{2}$ ratios increased. Such parameters as $\mathrm{S} / \mathrm{C}, \mathrm{H}_{2} \mathrm{~S} / \mathrm{SO}_{2}, \mathrm{~S} / \mathrm{Cl}$ and $\mathrm{F} / \mathrm{Cl}$ represent ratios of poorly soluble to readily-soluble gases. The change in values of these ratios which occurred against the background of temperature decrease is caused, in all appearance, by gradual decrease of the content of poorly-soluble gases in exhalations. In 1983-1984 the $\mathrm{S} / \mathrm{Cl}$ and $\mathrm{F} / \mathrm{Cl}$ ratios increased abruptly in the "Gremuchaya" solfataric gases while the tendency towards temperature decrease and other variations remained as before. Increase in $\mathrm{S} / \mathrm{Cl}$ and $\mathrm{F} / \mathrm{Cl}$ ratios is probably connected with the rise of ground-water level when the $\mathrm{HCl}$ absorption occurred. Simultaneously, the $\mathrm{HCl}$ content increased. The 

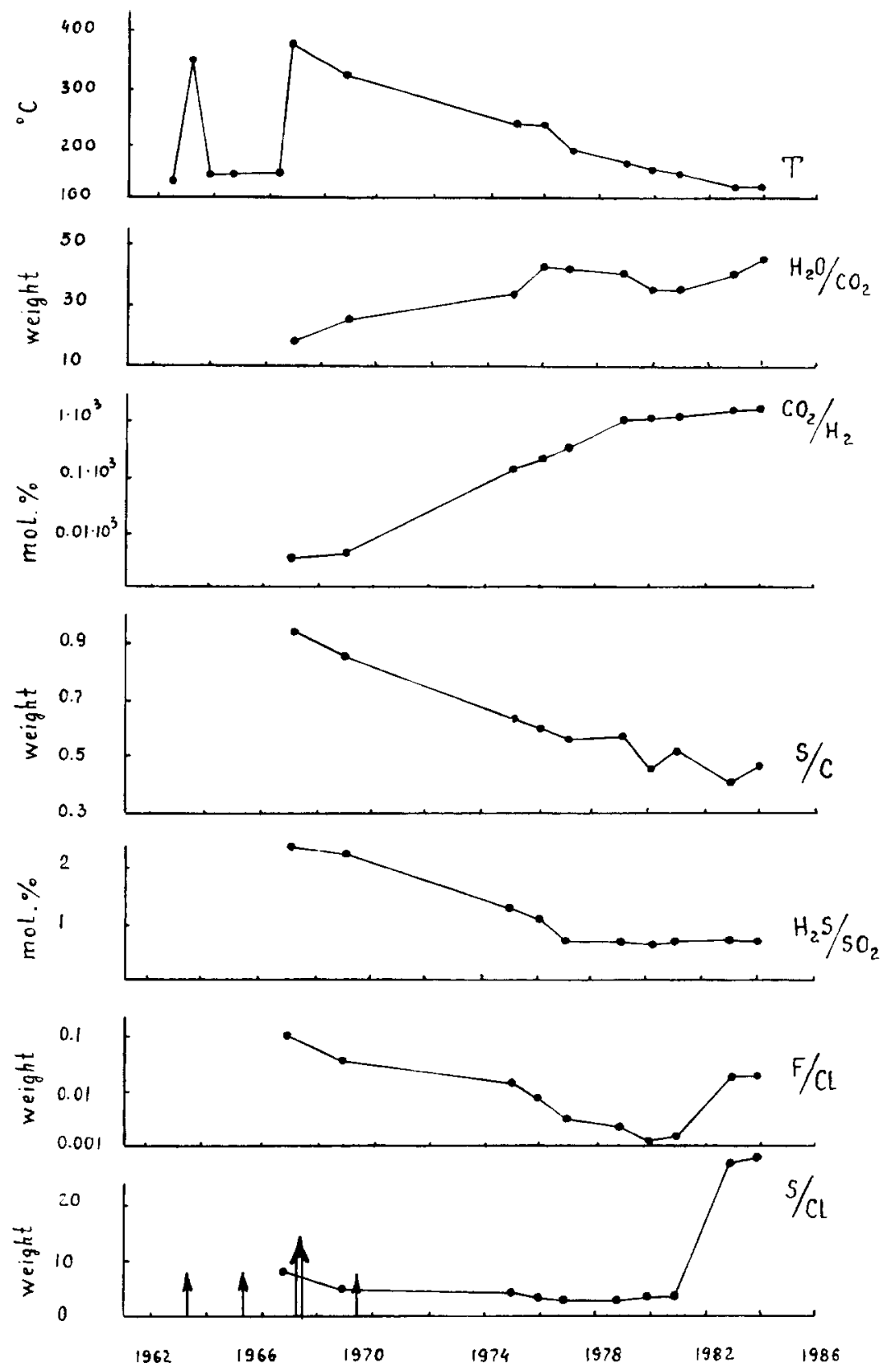

Fig. 4. Variations in temperature and gas ratios for the "Gremuchaya" solfatara depending on the activity of Ebeko (calculated based on analyses in Table I). Large arrow-the 1967 phreatic eruption, small arrows-intensification of gas emission. 

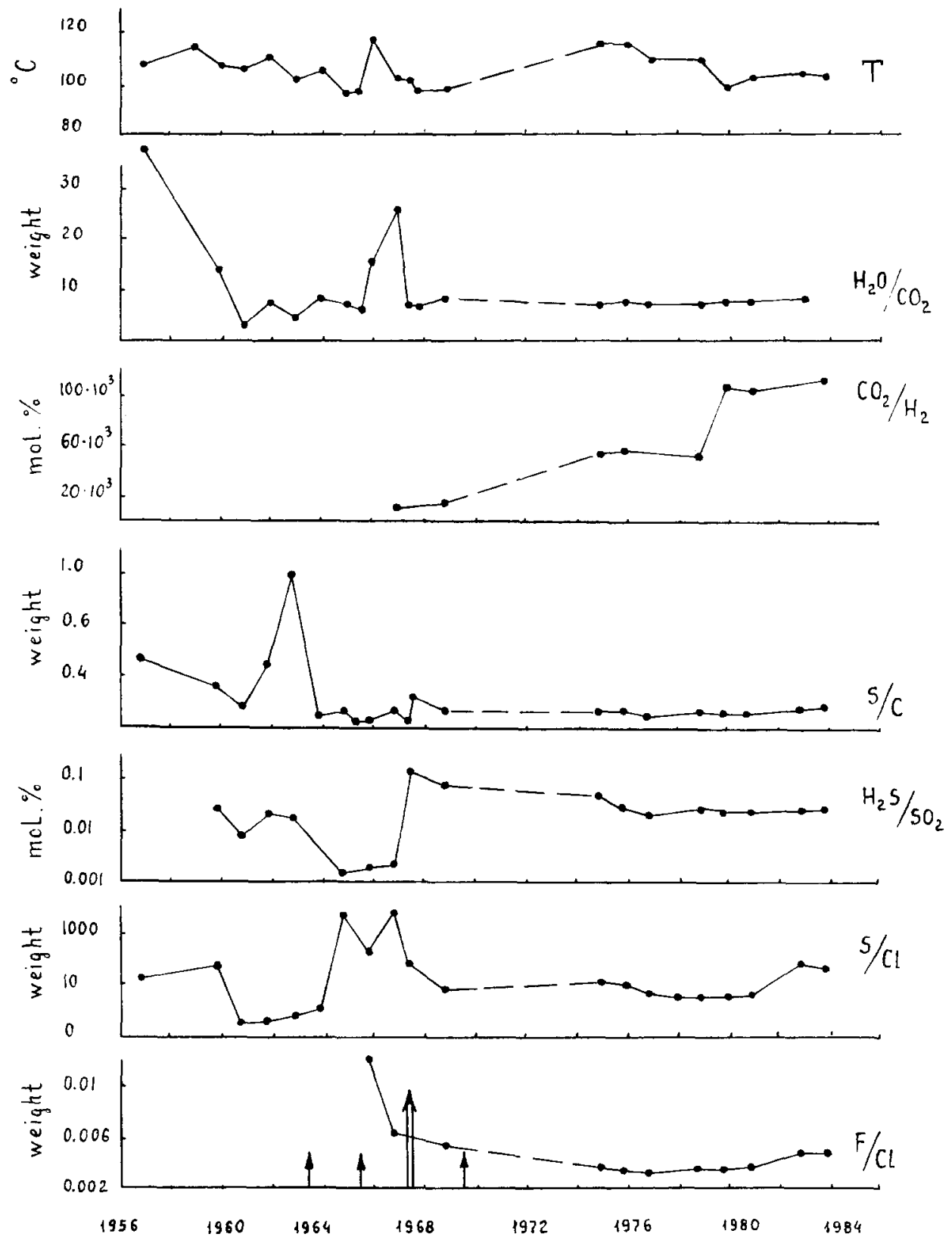

Fig. 5. Variations in temperature and gas ratios for the "Revushchie" solfataras depending on the activity of Ebeko (calculated from analyses in Table I). Large arrow-the 1967 phreatic eruption, small arrows-intensification of gas emission. 
temperature of solfataras in the region of the Eastern circus, $300 \mathrm{~m}$ southwest of the "Gremuchaya" solfatara, also increased and this apparently was caused by the ground-water runoff. Thus, at Ebeko the variation in composition and temperature of solfataras may be caused by the change of hydrodynamic conditions. It is precisely this phenomenon that explains the intensification of activity in the region of the Eastern circus.

The "Revushchie" solfataras within the Northeastern field were under observation from the middle of the nineteen-fifties (Fig. 5). The temperatures of solfataras fluctuated within the range of $100^{\circ} \mathrm{C}$, but during the intensification of volcanic activity in 1963 through 1967 their temperature increased. Then an abrupt variation in geochemical parameters was noted, namely an increase in the $\mathrm{H}_{2} \mathrm{O} / \mathrm{CO}_{2}, \mathrm{~S} / \mathrm{C}, \mathrm{H}_{2} \mathrm{~S} / \mathrm{SO}_{2}, \mathrm{~S} / \mathrm{Cl}$ and $\mathrm{F} / \mathrm{Cl}$ ratios. Prior to and after the period 1963-1967, the values of these ratios fluctuated within rather narrow ranges. In 1983 and 1984 an increase in $\mathrm{F} / \mathrm{Cl}$ and $\mathrm{S} / \mathrm{Cl}$ ratios was observed. As in the case of the "Gremuchaya" solfatara, this was caused by the rise of ground-water level and by $\mathrm{HCl}$ absorption.

Based on the above reported data, the eruptive cycle of Ebeko volcano consists of the following periods (see Fig. 3): pre-eruptive period from 1959 to 1966; eruptive period in 1967; post-eruptive period from 1967 to 1969 and intereruptive period from 1970 until the present time. Intensification of gas emission, increase in temperature and in $\mathrm{S} / \mathrm{C}, \mathrm{S} / \mathrm{Cl}, \mathrm{F} / \mathrm{Cl}$ and $\mathrm{H}_{2} \mathrm{~S} / \mathrm{SO}_{2}$ ratios for solfataric gases are noted during the pre-eruptive period. Temperatures, $\mathrm{H}_{2}$ and $\mathrm{CO}$ contents and $\mathrm{S} / \mathrm{C}, \mathrm{S} / \mathrm{Cl}, \mathrm{F} / \mathrm{Cl}$ and $\mathrm{H}_{2} \mathrm{~S} / \mathrm{SO}_{2}$ ratios become a maximum during the eruptive period. The decreases of temperature and other geochemical parameters are observed during the posteruptive period. Thus, the increase in temperature, $\mathrm{H}_{2}$ and $\mathrm{CO}$ appearance and the increase in $\mathrm{S} / \mathrm{C}, \mathrm{S} / \mathrm{Cl}, \mathrm{F} / \mathrm{Cl}$ and $\mathrm{H}_{2} \mathrm{~S} / \mathrm{SO}_{2}$ ratios may be considered to be precursors to the forthcoming eruptive period of Ebeko volcano. These geochemical parameters were used as the basis for predicting the 1967 phreatic eruption half a year in advance.

It is noteworthy that all parameters, including the temperature and thermal survey data, must be used in monitoring the state of the volcano. The life of the volcano is very complex and fluctuations of some geochemical parameters may be caused not only by magma activation but, as in 1983 and 1984, by change in hydrodynamic conditions or, e.g., by tectonic movements. The gas-hydrothermal activity and phreatic eruptions, as well as lack of seismological precursors to an eruption (Menyailov et al., 1969), are typical of volcanoes of the Ebeko type; therefore the geochemical method of prediction is the most acceptable. 


\section{The Origin of Solfataric Gases as Shown by Isotope Data}

Isotopic ratios of hydrogen, oxygen, argon, helium, neon, krypton and xenon were studied using gas and condensate samples from the "Gremuchaya" and "Revushchaya" solfataras. As is seen from Table 3, these ratios differed considerably from those of local meteoric waters and the atmosphere. We may suppose that a considerable amount of noble gases from both solfataras is of abyssal (mantle) origin. This is characteristic also of $\mathrm{CO}_{2}\left(\delta^{13} \mathrm{C}\right.$ from -7 to $-11 \%$, PDB $)$. However, the quota of deep components in the gases of the "Gremuchaya" solfatara is higher in comparison with those of the "Revushchie" solfataras; this may be accounted for by the different sites of the solfataras. The "Gremuchaya" solfatara occurs in the near-summit part of the active cone. The "Revushchie" solfataras occur hypsometrically lower, where the ground-water table rises close to the surface and where meteoric waters might have an influence. In fact, the values of $\delta \mathrm{D}$ and $\delta^{18} \mathrm{O}$ for the condensate of the "Revushchie" solfataras are close to those of local meteoric waters.

In its isotopic composition of hydrogen, the condensate from the "Gremuchaya" solfatara hardly varies from local meteoric waters apparently representing a mixture of meteoric and sea waters. A shift of $\delta^{18} \mathrm{O}$ values assumes the presence of a considerable amount of magmatic water in the composition of the "Gremuchaya" solfataric steam. During the observational period, the values of $\delta^{18} \mathrm{O}$ for the steam condensates of both

\section{TABLE 3}

The isotopic composition of $\mathrm{H}_{2} \mathrm{O}$ and noble gases at Ebeko volcano compared with the meteoric and atmospheric values.

\begin{tabular}{lccc} 
Isotopic & $\begin{array}{c}\text { "Gremuchaya" } \\
\text { solfatara, } \\
150^{\circ} \mathrm{C}\end{array}$ & $\begin{array}{c}\text { "Revushchaya" } \\
\text { solfatara, } \\
1000^{\circ}\end{array}$ & $\begin{array}{c}\text { Local meteoric } \\
\text { waters and } \\
\text { atmosphere }\end{array}$ \\
${ }^{\delta \mathrm{D}, \% 00}$ SMOW & -36 & -61 & $-70--86$ \\
$\delta^{19} \mathrm{O}, \%{ }^{0} \mathrm{SMOW}$ & $-2.5-+1.2$ & -8.5 & $-11.3-11.8$ \\
${ }^{3} \mathrm{He} /{ }^{4} \mathrm{He}$ & $6.6 \times 10^{-6}$ & $8.44 \times 10^{-6}$ & $1.4 \times 10^{-6}$ \\
${ }^{40} \mathrm{Ar} /{ }^{36} \mathrm{Ar}$ & $314-341$ & 322 & 295 \\
${ }^{4} \mathrm{He} /{ }^{40} \mathrm{Ar}$ & 0.33 & 0.031 & 0.00056 \\
${ }^{4} \mathrm{He} /{ }^{20} \mathrm{Ne}$ & 254 & 11.8 & 0.31 \\
${ }^{38} \mathrm{Ar} /{ }^{132} \mathrm{Xe}$ & 74.2 & 123 & 254 \\
${ }^{38} \mathrm{Ar} /{ }^{84} \mathrm{Kr}$ & 5.35 & 6.58 & 9.07 \\
${ }^{20} \mathrm{Ne} /{ }^{36} \mathrm{Ar}$ & 0.41 & 0.795 & 0.523 \\
\hline
\end{tabular}

$\delta^{18} \mathrm{O}$ and $\delta \mathrm{D}$ were determined by V. Vetstein (Kiev Institute of Physics of Minerals and Geochemistry) and noble gases were determined by A. Rozhkov (Institute of Volcanology). 


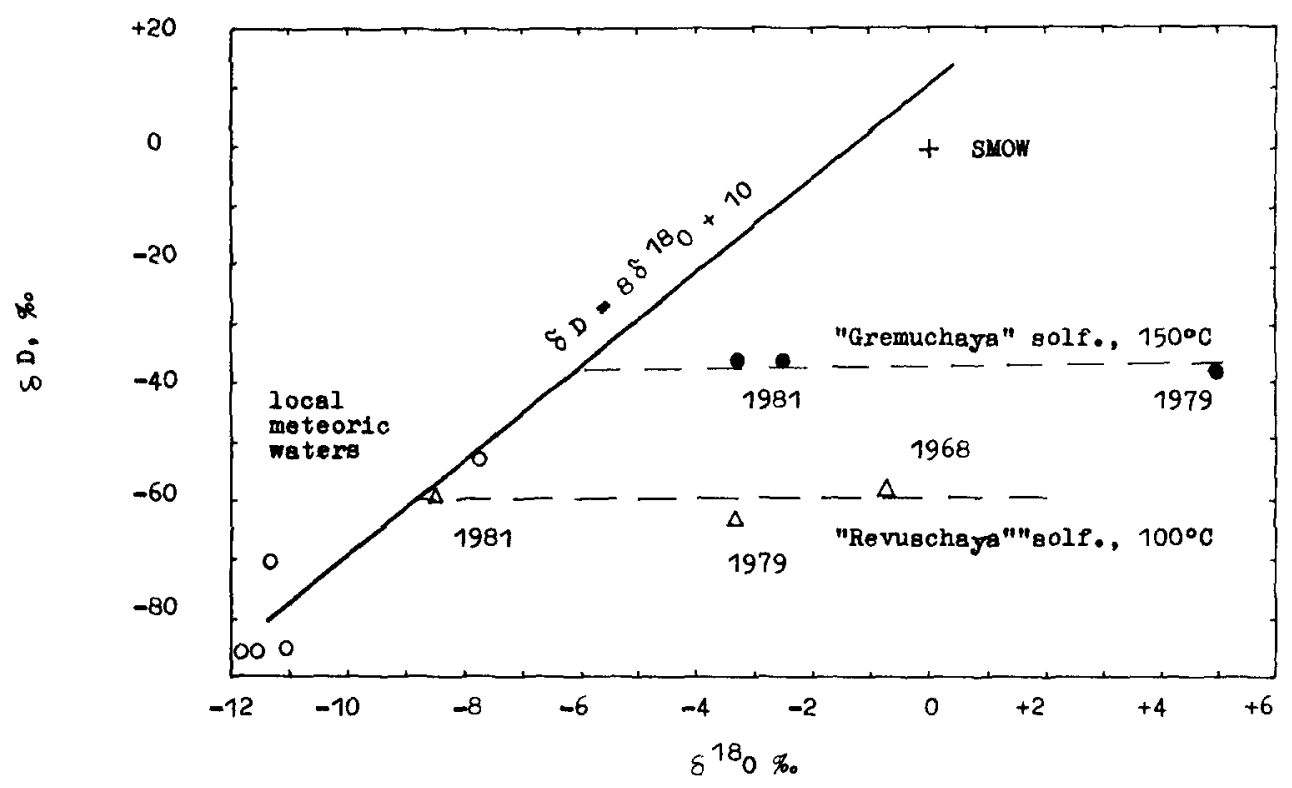

Fig. 6. Temporal variations in isotopic composition of water condensates from the "Gremuchaya" and "Revushchie" solfataras in a $\delta \mathrm{D}-\delta^{18} \mathrm{O}$ diagram.

solfataras decreased gradually and at present have reached the values for local meteoric waters (Fig. 6); i.e. the quota of magmatic water in the composition of solfataric steam decreased. Thus, the variation in $\delta^{18} \mathrm{O}$ value for the solfataric steam condensates may be used in monitoring the state of the volcano, along with other distinguishing geochemical parameters.

\section{CONCLUSIONS}

Based on studies of the chemical and isotopic composition of solfataric gases carried out since 1957, a geochemical model of the activity of Ebeko was developed (Fig. 7). This model may help to explain the variations in gas composition connected with volcanic activity satisfactorily.

It is supposed that there is a sea-water aquifer above the shallow magma chamber. Above the sea-water aquifer, fresh ground-waters are accumulated. Magmatic emanations ascending to the surface leak through the aquifers. As a result, the decrease in temperature of emanations, condensation and significant dilution of magmatic water, as well as the loss of readily-soluble acidic gases, haloid in the first instance, occur. When the magma becomes more active in the pre-eruptive period the flux of magmatic emanations increases. In this connection, the temperature of solfataric gases, the amount of magma components and, above all, the quota of relatively 


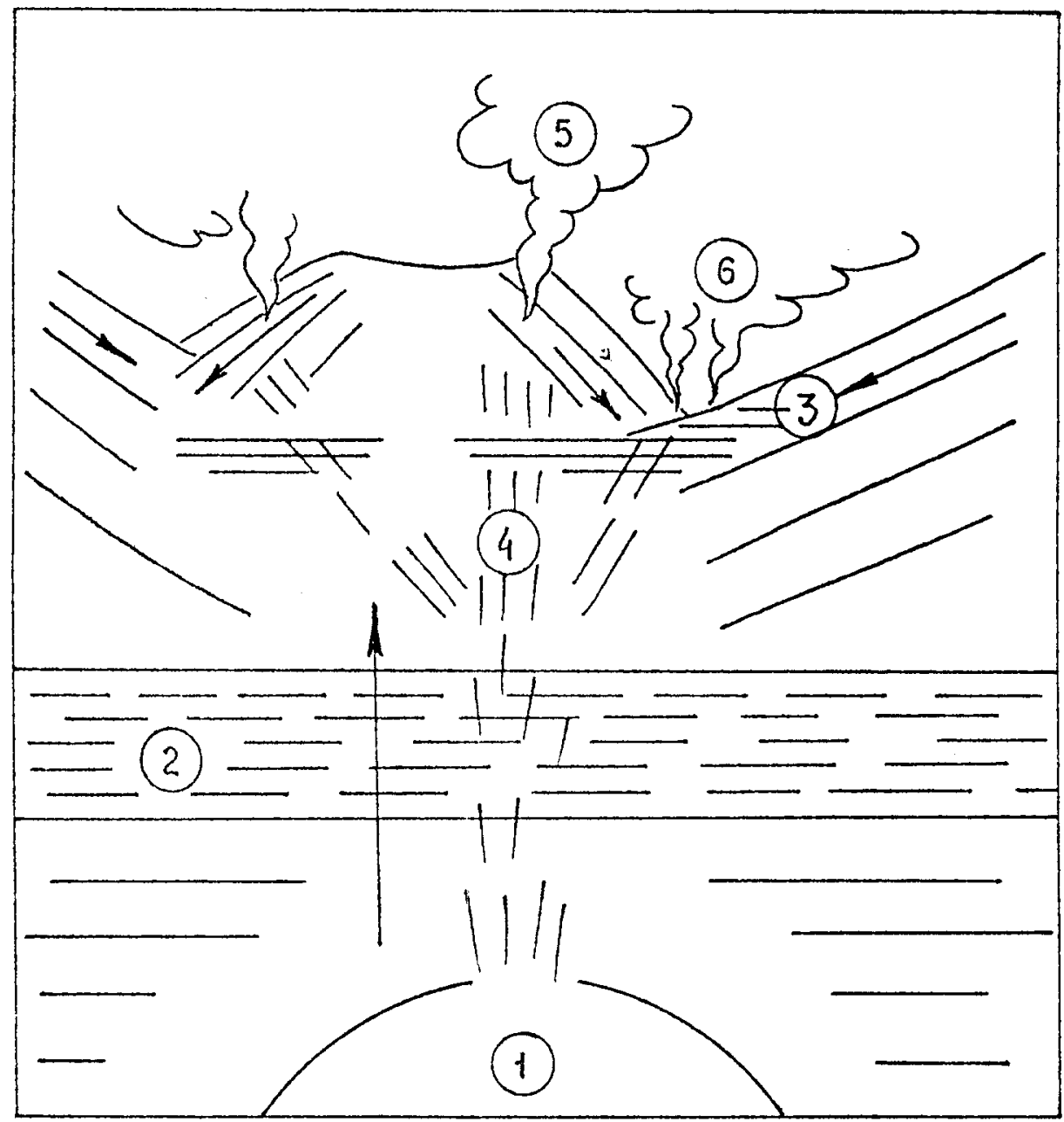

Fig. 7. The model of activity of Ebeko. 1. magma chamber; 2. sea-water aquifer; 3. ground-waters; 4. magmatic emanation flux; 5. "Gremuchaya" solfatara; 6. "Revushchie" solfataras.

poorly-soluble gases in the magma increase (Menyailov and Nikitina, 1967; Menyailov, 1976). All this, against the background of "gas-water" interaction accompanied by a loss of emanations readily-soluble in water, occurs along with increasing $\mathrm{S} / \mathrm{C}, \mathrm{S} / \mathrm{Cl}, \mathrm{F} / \mathrm{Cl}$, and $\mathrm{H}_{2} \mathrm{~S} / \mathrm{SO}_{2}$ ratios.

The main results of monitoring the Ebeko volcano during the period from 1964 to the present time, in the course of which a phreatic eruption occurred in 1967, are as follows: the distinction of the eruptive cycle and periods of volcanic activity; the determination of variations in the main geochemical parameters (the temperature of gases, S/C, S/Cl, F/Cl, $\mathrm{H}_{2} \mathrm{~S} / \mathrm{SO}_{2}, \mathrm{H}_{2} \mathrm{O} / \mathrm{CO}_{2}, \mathrm{CO}_{2} / \mathrm{H}_{2}$ and $\delta{ }^{18} \mathrm{O}$ values) depending on the change of 
activity of the volcano; and the determination of the main geochemical parameter values during the 1967 phreatic eruption. It is supposed that the increase in the temperature of gases and in geochemical parameter values may be precursors to future eruptions.

\section{REFERENCES}

Basharina, L. A., 1956. Fumaroles of Sheveluch volcano in September-December 1953, Bull. Volcanol. St., 24: 6-9 (in Russian).

Basharina, L. A., 1963. Exhaltations of Klyuchevskoy parasitic craters during the various stages of lava cooling. In: Volcanism of Kamchatka and Other Regions of the USSR, pp. 133-150, Moscow, Nauka (in Russian).

Basharina, L. A., 1966. Exhaltations of Bezymianny acid lavas. In: Recent Volcanism, pp. 3-16, Moscow, Nauka (in Russian).

Basharina, L. A. and Khramova, G. G., 1971. The state of Ebeko volcano in 1966-1967, Bull. Volcanol. St., 47: $28-39$ (in Russian).

Experience in Cooperative Study of the Region of Recent and Youngest Volcanism: an Example from the Vernadsky Ridge, Paramushir Island, 1966, pp. 206, Yuzhno-Sakhalinsk, Proc. SakhNII AN SSSR. Iss.16 (in Russian).

Fedotov, S. A., 1982. Evaluation of heat and pyroclast discharge by volcanic eruptions and fumaroles, based on the height of their plumes and clouds, Volcanol. and Seismol., 4: 3-28 (in Russian).

Gorshkov, G. S., 1967. The volcanism of the Kurile island arc, pp. 287, Moscow, Nauka (in Russian).

Kirsanov, I. T., Serafimova, E. K., Sidorov, S. S., Trubenko, V. F., Farberov, A. I., Fedorchenko, V. I. and Shilov, V. N., 1964. The eruption of Ebeko volcano in March-April, 1963, Bull. Volcanol. St., 36: 66-72 (in Russian).

Menyailov, I. A., 1976. The dependence of the composition of volcanic gases on the state of volcanic activity and geochemical prediction of eruptions, Bull. Volcanol. St., 52: 42-48 (in Russian).

Menyailov, I. A. and Nikitina, L. P., 1967. On the behaviour of sulfur and chlorine in the fumarolic gases before the intensification of volcanic activity. In: Volcanism and Geochemistry of Its Products, pp. 72-81, Moscow, Nauka (in Russian).

Menyailov, I. A., Nikitina, L. P. and Khramova, G. G., 1969. The gashydrothermal eruption of Ebeko volcano in February-April, 1967, Bull. Volcanol. St., 45: 3-6 (in Russian).

Menyailov, I. A., Nikitina, L. P. and Shapar, V. N., 1980. Geochemistry of exhalations from the 1975-1976 Great Tolbachik Fissure Eruption, pp. 216, Moscow, Nauka (in Russian).

Nekhoroshev, A. S., 1960. Theoretical conditions and heat flow of Ebeko volcano in Paramushir Island, Bull. Volcanol. St., 29: 38-46 (in Russian).

Piyp, B. I., 1956. Klyuchevskoy volcano and its eruptions in 1944-1945 and in the past, pp. 309, Moscow, Izd.AN SSSR (in Russian).

Scripko, K. A., Filkova, I. M. and Khramova, G. G., 1966. The state of Ebeko volcano in summer, 1965. Bull. Volcanol. St., 42: 42-55 (in Russian).

Surina, L. V. and Voronova, L. G., 1964. The significance of studies on the volcanic gas chemical composition for eruption prediction, Geol. and Geophys., 7: 66-69 (in Russian).

Voronova, L. G. and Sidorov, S. S., 1966. Comparative characteristics of fumarolic gases of some volcanoes in the Kurile Islands. In: Recent Volcanism, pp. 146-152, Moscow, Nauka (in Russian). 